\title{
Influence of Weed Management on Weed Dynamics and Yield of Machine Sown Pigeonpea [Cajanus cajan (l.) Millsp.] Under Dryland Conditions
}

\author{
P. Kathirvelan* \\ Tapioca and Castor Research Station, Tamil Nadu Agricultural University, P.G. Palayam, \\ Yethapur - 636 119, Salem, Tamil Nadu, India \\ *Corresponding author
}

\begin{tabular}{|l|}
\hline Ke y w o r d s \\
$\begin{array}{l}\text { Influence of weed } \\
\text { management, Weed } \\
\text { dynamics. }\end{array}$ \\
\hline Article Info \\
\hline $\begin{array}{l}\text { Accepted: } \\
\text { 24 September } 2017 \\
\text { Available Online: } \\
\text { 10 November 2017 }\end{array}$ \\
\hline
\end{tabular}

\section{Introduction}

Pigeonpea is an important multipurpose legume crop mainly cultivated under rainfed ecosystem. It is short lived perennial shrub which is traditional cultivated as annual crop during Kharif season in India. It is a good source of protein (20-22 \%), vitamins (thiamine, riboflavin, niacin and choline) and minerals ( $\mathrm{Fe}, \mathrm{Ca}, \mathrm{P}, \mathrm{S}$ and $\mathrm{K})$. Hence, it is gaining worldwide importance and can be used as food, fodder and fuel besides it enriches the soil through symbiotic nitrogen fixation, releases soil bound phosphorus, recycles the soil nutrients and add organic matter which make pigeonpea ideal crop for sustainable agriculture (Saxena, 2008). It has wider adaptability with drought tolerance owing to its deep root system and performs very well even under moisture stress condition. Since the scope for increasing the area of pigeonpea in the country is very limited and increasing its productivity is the only viable option through managing various 
biotic and abiotic stresses. Among the various biotic factors limiting the production and productivity of pigeonpea, weeds are of prime importance. In general, pigeonpea is cultivated with wider inter row spacing and slow initial growth, weeds such as cyperaceous, narrow and broad leaved weeds pose a serious threat to its productivity which may leads to severe yield reduction even up to 80 per cent (Talnikar et al., 2008). The critical period is during the first eight weeks after sowing. Losses in grain yield caused by the weeds in pigeonpea are reported to the extent of 60 per cent (Kandasamy, 1999). Hence, timely weed control is very important for realizing higher productivity in pigeon pea under rainfed condition.

Though manual method of weed control is quite effective, but it is laborious, time consuming and cumbersome now a days. Hence, effective weed management strategy with new molecules of pre and early post and post emergence herbicide application in integration with agronomic practices viz., power weeding is pivotal for obtaining higher yield. With this view, present field experiment was undertaken to find out the effect of different weed management practices on growth, yield and economics of pigeonpea under rainfed condition.

\section{Materials and Methods}

Field experiments were conducted at Dryland Agricultural Research Station Experimental Farm, Chettinad during Kharif 2013 and 2014 season, to find out the effect of different weed management practices in machine sown pigeon pea (var. VBN 2) under dry land conditions. The experiment consisted of following treatments viz., power weeder weeding once at 20 DAS, power weeder weeding twice at 20 and $40 \mathrm{DAS}$, power weeder weeding once at $20 \mathrm{DAS}+$ one hand weeding, power weeder weeding twice (20
DAS and 40 DAS) + one hand weeding, mulching with cumbu napier trash @ 5 t/ha, imazethapyr@50 g a.i ha ${ }^{-1}$ and quizalofop ethyl @ $50 \mathrm{~g} \mathrm{a.i} \mathrm{ha}{ }^{-1}$ at 15 DAS, hand weeding at 20 and 40 DAS and these treatments were compared with unweeded control. The trial was laid out in randomized block design with three replications. The long duration variety VBN 2 was chosen and sowing was done by tractor drawn seed drill with a spacing of $90 \mathrm{~cm} \mathrm{X} 30 \mathrm{~cm}$. The soils of experimental field represent red sandy loam type. The available nutrient status of the field was low in $\mathrm{N}$ (212 $\left.\mathrm{kg} \mathrm{ha}^{-1}\right)$, medium in phosphorus $\left(21 \mathrm{~kg} \mathrm{ha}^{-1}\right)$ and low in potash $\left(148 \mathrm{~kg} \mathrm{ha}^{-1}\right)$.

The physic-chemical properties of soil are furnished in table 1. The germination percentage of seed was 98 and the required plant population per unit area as per the treatment was maintained with thinning which was carried out on 15 days after sowing. The recommended doses of inorganic fertilizers (12.5:25:12.5 kg NPK ha ${ }^{-1}$ ) were applied along the planting rows as urea, DAP and Muriate of Potash and covered with soil. All other plant protection measures were adopted as per the technical programme.

The total number of matured pods from the five plants was counted and mean arrived. Pods from each treatment were randomly selected and shelled. From this, a representative sample of 100 grains was randomly picked out and weighed by using an electronic balance and expressed in $\mathrm{g} 100^{-1}$ grains. The harvested pods from the net plot were sun dried, cleaned and the pod yield was recorded for the individual treatment after drying to 12 per cent seed moisture and expressed in $\mathrm{kg} \mathrm{ha}^{-1}$. Dry matter of weeds was recorded at harvest on plot basis after sundrying for about 7 days and then converted into $\mathrm{kg} \mathrm{ha}^{-1}$. Weed control efficiency (WCE) was calculated using the following formula 
WCE $(\%)=[($ Dry matter of weeds in unweeded control - Dry matter of weeds in treated plot) $\times 100$ ] / Dry matter of weeds in unweeded control plot

\section{Results and Discussion}

Predominant weed flora in the experimental field

The predominant weed flora observed in the experimental site were Brachiaria reptans, Dactyloctinium aegyptium, Cynodon dactylon, Perotis indica, Panicum javanicum under grass weed category, sedges such as Cyperus difformis, Cyperus rotundus, Fimbristylis argentea and broad leaf weeds viz., Commelina benghalensis, Abutilon indicum, Borreria hispida, Corchorus tridens, Cyanotis cucullata, Indigofera trita and Mollugo sp.

\section{Soil moisture under varied weed management practices}

Soil moisture was measured using soil moisture pulse meter (Model MPM-160 B) at $15 \mathrm{~cm}$ soil depth. The data recorded on soil moisture at $15 \mathrm{~cm}$ soil depth during the critical period of crop growth (Kharif 2013 and 2014) revealed that the highest soil moisture was observed at 75 and 45 DAS followed by 105 and 60 DAS, respectively and the lowest values were observed at 45 and 90 DAS, respectively. With regard to effect of different weed management practices on soil moisture conservation, invariably at all the stages of crop growth, the highest soil moisture retention capacity was registered in mulched plot@5.0 t ha ${ }^{-1}$. The soil moisture retention capacity ranged from 0.1 per cent to 18.9 per cent and the highest soil moisture of 18.9 per cent was recorded at vegetative stage of the crop growth under mulched treatment. The details of soil moisture recorded at $15 \mathrm{~cm}$ soil depth are given in table 2.

Effect of treatment on weed density, weed dry weight and weed control efficiency

Between the two years of study, higher weed density was observed during 2013-14 year as compared to 2014-15. The mean data on weed density recorded during flowering stage of the crop showed that lower weed density was recorded under power weeder weeding twice at 20 and 40 DAS + hand weeding which was statistically on par with hand weeding twice at 20 and 40 DAS and power weeder weeding once at 20 DAS coupled with hand weeding.

Table.1 Physico-chemical properties of the experimental field

\begin{tabular}{ll}
\hline Particulars & Value \\
\hline $\mathrm{P}^{\mathrm{H}}$ & 6.5 \\
$\mathrm{EC}(\mathrm{dS} \mathrm{m}$ & -1 \\
Organic carbon $(\%)$ & 4.0 \\
Nitrogen $\left(\mathrm{kg} \mathrm{ha}^{-1}\right)$ & 0.38 \\
Phosphorus $\left(\mathrm{kg} \mathrm{ha}^{-1}\right)$ & $212 \mathrm{~kg} \mathrm{ha}^{-1}$ \\
Potassium $\left(\mathrm{kg} \mathrm{ha}^{-1}\right)$ & $21 \mathrm{~kg} \mathrm{ha}^{-1}$ \\
Textural class & $148 \mathrm{~kg} \mathrm{ha}^{-1}$ \\
Bulk density $(\mathrm{g} \mathrm{CC}-1)$ & Red sandy loam \\
\hline
\end{tabular}


Table.2 Soil moisture (per cent) recorded at $15 \mathrm{~cm}$ depth during the cropping period (Kharif 2013 and 2014)

\begin{tabular}{|c|c|c|c|c|c|c|c|c|c|c|c|c|c|c|c|c|}
\hline \multirow{2}{*}{ Stage DAS } & \multicolumn{2}{|c|}{$\mathbf{T}_{1}$} & \multicolumn{2}{|c|}{$\mathbf{T}_{2}$} & \multicolumn{2}{|c|}{$\mathbf{T}_{3}$} & \multicolumn{2}{|c|}{$T_{4}$} & \multicolumn{2}{|c|}{$\mathbf{T}_{5}$} & \multicolumn{2}{|c|}{$\mathrm{T}_{6}$} & \multicolumn{2}{|c|}{$\mathbf{T}_{7}$} & \multicolumn{2}{|c|}{$\mathbf{T}_{8}$} \\
\hline & 2013 & 2014 & 2013 & 2014 & 2013 & 2014 & 2013 & 2014 & 2013 & 2014 & 2013 & 2014 & 2013 & 2014 & 2013 & 2014 \\
\hline 15 & 0 & 3.5 & 0 & 3.4 & 0 & 3.5 & 0 & 3.7 & 1.7 & 7.5 & 0 & 4.1 & 3.6 & 0 & 0.2 & 3.8 \\
\hline 30 & 0 & 0.8 & 0 & 1.0 & 0 & 0.8 & 0 & 0.7 & 0 & 3.6 & 0 & 0.8 & 0.7 & 0 & 0 & 0.8 \\
\hline 45 & 0 & 13.6 & 0 & 13.5 & 0 & 13.2 & 0 & 13.4 & 0 & 18.9 & 0 & 13.7 & 13.2 & 0 & 0 & 14.1 \\
\hline 60 & 7.5 & 9.2 & 7.6 & 9.1 & 6.9 & 9.4 & 6.5 & 8.9 & 9.6 & 14.5 & 7.8 & 9.1 & 9.2 & 6.4 & 6.9 & 8.5 \\
\hline 75 & 12.9 & 4.5 & 13.1 & 4.7 & 13.4 & 4.8 & 13.2 & 5.0 & 14.1 & 7.8 & 12.5 & 4.8 & 5.0 & 12.8 & 12.4 & 4.9 \\
\hline 90 & 5.8 & 0.5 & 5.6 & 0.4 & 6.2 & 0.2 & 6.1 & 0.1 & 6.7 & 3.5 & 5.2 & 0.5 & 0.4 & 6.1 & 5.0 & 0.5 \\
\hline 105 & 9.2 & 3.2 & 8.8 & 3.5 & 9.2 & 3.3 & 9.5 & 3.5 & 10.2 & 8.7 & 8.2 & 3.2 & 3.4 & 7.9 & 7.8 & 3.3 \\
\hline 120 & 4.2 & 0 & 4.1 & 0 & 4.6 & 0 & 4.4 & 0 & 5.1 & 0.4 & 1.5 & 0 & 0 & 3.5 & 1.8 & 0 \\
\hline 135 & 6.1 & 0 & 5.9 & 0 & 6.4 & 0 & 6.8 & 0 & 8.7 & 0 & 4.6 & 0 & 0 & 6.2 & 4.0 & 0 \\
\hline 150 & 0 & 0 & 0 & 0 & 0 & 0 & 0 & 0 & 0 & 0 & 0 & 0 & 0 & 0 & 0 & 0 \\
\hline
\end{tabular}

Table.3 Effect of different weed management practices on weed density, dry weight and WCE in machine sown pigeonpea at flowering stage

\begin{tabular}{|c|c|c|c|c|c|c|c|c|c|}
\hline \multirow{2}{*}{ Treatments } & \multicolumn{3}{|c|}{ Weed density $\mathrm{m}^{-2}$} & \multicolumn{3}{|c|}{ Weed dry weight $\left(\mathrm{g} \mathrm{m}^{-2}\right)$} & \multicolumn{3}{|c|}{ WCE (\%) } \\
\hline & 2013-14 & 2014-15 & Mean & 2013-14 & 2014-15 & Mean & 2013-14 & 2014-15 & Mean \\
\hline $\mathrm{T}_{1}$. Power weeder weeding at $20 \mathrm{DAS}$ & $8.29(68.2)$ & $4.64(21.0)$ & $6.72(44.6)$ & $7.87(61.4)$ & $6.21(38.1)$ & $\begin{array}{c}7.09 \\
(49.8)\end{array}$ & 32.9 & 23.8 & 28.4 \\
\hline $\mathrm{T}_{2}$. Power weeder weeding at 20 and $40 \mathrm{DAS}$ & $7.99(63.4)$ & $4.14(16.6)$ & $6.36(40.0)$ & $6.54(42.3)$ & $5.38(28.4)$ & $\begin{array}{c}5.99 \\
(35.4)\end{array}$ & 53.7 & 43.2 & 48.5 \\
\hline $\mathrm{T}_{3}$. Power weeder weeding at $20 \mathrm{DAS}+$ hand weeding & $4.75(22.1)$ & $3.99(15.4)$ & $4.39(18.8)$ & $5.63(31.2)$ & $4.01(15.6)$ & $\begin{array}{c}4.89 \\
(23.4)\end{array}$ & 65.9 & 68.8 & 67.4 \\
\hline $\begin{array}{l}\mathrm{T}_{4} \text {. Power weeder weeding at } 20 \text { and } 40 \mathrm{DAS}+\text { hand } \\
\text { weeding }\end{array}$ & $3.71(13.3)$ & $3.36(10.8)$ & $3.55(12.1)$ & $4.38(18.7)$ & $3.29(10.3)$ & $\begin{array}{l}3.87 \\
(14.5)\end{array}$ & 79.6 & 79.4 & 79.5 \\
\hline $\mathrm{T}_{5}$. Mulching @ $5 \mathrm{t} / \mathrm{ha}$ & $7.54(56.4)$ & $4.69(21.5)$ & $6.28(39.0)$ & $6.25(38.6)$ & $4.76(22.2)$ & $\begin{array}{c}5.56 \\
(30.4)\end{array}$ & 57.8 & 55.6 & 56.7 \\
\hline $\begin{array}{l}\text { T6. Imazethapyr @ } 50 \mathrm{~g} \text { a.i / ha and Quizalofop ethyl } \\
@ 50 \mathrm{~g} \text { a.i / ha at } 15 \mathrm{DAS}\end{array}$ & $7.22(51.7)$ & $4.30(18.0)$ & $5.95(34.9)$ & $5.92(34.5)$ & $4.55(20.2)$ & $\begin{array}{c}5.27 \\
(27.3)\end{array}$ & 62.3 & 59.7 & 61.0 \\
\hline $\mathrm{T}_{7}$. Hand weeding at 20 and $40 \mathrm{DAS}$ & $4.57(20.4)$ & $3.65(12.8)$ & $4.14(16.6)$ & $4.69(21.5)$ & $3.61(12.5)$ & $\begin{array}{c}4.18 \\
(17.0)\end{array}$ & 76.5 & 75.0 & 75.8 \\
\hline $\mathrm{T}_{8}$. Unweeded control & $9.06(81.5)$ & $6.04(36.0)$ & $7.70(58.8)$ & $9.59(91.5)$ & $7.11(50.0)$ & $\begin{array}{c}8.44 \\
(70.8)\end{array}$ & 0.0 & 0.0 & 0.0 \\
\hline S.Ed & 7.9 & 3.1 & 5.5 & 7.6 & 4.2 & 5.7 & - & - & - \\
\hline $\mathrm{CD}(\mathrm{P}=0.05)$ & 16.8 & 6.5 & 11.6 & 15.4 & 8.9 & 12.1 & - & - & - \\
\hline
\end{tabular}

Values in parentheses are original and data are transformed to square root transformation $(\mathrm{x}+0.5)$ 
Table.4 Effect of different weed management practices on plant height, primary and secondary branches plant ${ }^{-1}$ of pigeonpea $^{-}$

\begin{tabular}{|c|c|c|c|c|c|c|c|c|c|}
\hline \multirow{2}{*}{ Treatments } & \multicolumn{3}{|c|}{ Plant Height $(\mathrm{cm})$ at harvest } & \multicolumn{3}{|c|}{ Primary Branches Plant $^{-1}$} & \multicolumn{3}{|c|}{ Secondary Branches Plant ${ }^{-1}$} \\
\hline & 2013-14 & 2014-15 & Mean & 2013-14 & 2014-15 & Mean & 2013-14 & 2014-15 & Mean \\
\hline $\mathrm{T}_{1}$. Power weeder weeding at $20 \mathrm{DAS}$ & 140.5 & 180.2 & 160.4 & 3.2 & 15.75 & 9.5 & 23.0 & 23.0 & 23.0 \\
\hline $\mathrm{T}_{2}$. Power weeder weeding at 20 and $40 \mathrm{DAS}$ & 146.6 & 187.2 & 166.9 & 4.0 & 16.25 & 10.1 & 24.8 & 25.0 & 24.9 \\
\hline $\mathrm{T}_{3}$. Power weeder weeding at $20 \mathrm{DAS}+$ hand weeding & 165.2 & 196.5 & 180.9 & 4.2 & 18.00 & 11.1 & 32.4 & 26.7 & 29.6 \\
\hline $\mathrm{T}_{4}$. Power weeder weeding at 20 and $40 \mathrm{DAS}+$ hand & 171.2 & 204.5 & & 5.0 & 20.75 & & 37.4 & 35.5 & \\
\hline weeding & & & 187.9 & & & 12.9 & & & 36.5 \\
\hline T. Mulching@5 t/ha & 147.6 & 217.0 & 182.3 & 4.2 & 18.75 & 11.5 & 26.8 & 33.7 & 30.3 \\
\hline $\begin{array}{l}\text { T6. Imazethapyr @ } 50 \mathrm{~g} \text { a.i / ha and Quizalofop ethyl @ } \\
50 \text { g a.i / ha at } 15 \text { DAS }\end{array}$ & 155.9 & 178.5 & 167.2 & 4.2 & 16.00 & 10.1 & 28.9 & 25.2 & 27.1 \\
\hline $\mathrm{T}_{7}$. Hand weeding at 20 and $40 \mathrm{DAS}$ & 167.6 & 194.7 & 181.2 & 4.4 & 18.25 & 11.3 & 35.4 & 32.1 & 33.8 \\
\hline $\mathrm{T}_{8}$. Unweeded control & 133.8 & 177.2 & 155.5 & 3.0 & 14.00 & 8.5 & 17.6 & 16.2 & 16.9 \\
\hline S.Ed & 7.5 & 7.4 & 7.4 & 0.28 & 1.01 & 0.6 & 1.68 & 1.19 & 1.43 \\
\hline $\mathrm{CD}(\mathrm{P}=0.05)$ & 15.3 & 15.3 & 15.3 & 0.14 & 2.09 & 1.1 & 3.43 & 2.48 & 2.95 \\
\hline
\end{tabular}

Table.5 Effect of different weed management practices on pods plant ${ }^{-1}$, test weight and grain yield of pigeonpea

\begin{tabular}{|c|c|c|c|c|c|c|c|c|c|}
\hline \multirow[t]{2}{*}{ Treatments } & \multicolumn{3}{|c|}{ No. of pods plant ${ }^{-1}$} & \multicolumn{3}{|c|}{ Test weight $(\mathrm{g})$} & \multicolumn{3}{|c|}{ Grain yield $\left(\mathrm{kg} \mathrm{ha}^{-1}\right)$} \\
\hline & 2013-14 & 2014-15 & Mean & 2013-14 & 2014-15 & Mean & 2013-14 & 2014-15 & Mean \\
\hline $\mathrm{T}_{1}$. Power weeder weeding at $20 \mathrm{DAS}$ & 95.7 & 173.3 & 134.5 & 6.85 & 8.33 & 7.59 & 385 & 653 & 519 \\
\hline $\mathrm{T}_{2}$. Power weeder weeding at 20 and 40 DAS & 145.9 & 199.3 & 172.6 & 7.01 & 8.79 & 7.90 & 580 & 728 & 654 \\
\hline $\begin{array}{l}\mathrm{T}_{3} \text {. Power weeder weeding at } 20 \mathrm{DAS}+\text { hand } \\
\text { weeding }\end{array}$ & 188.8 & 204.2 & 196.5 & 7.04 & 8.84 & 7.94 & 864 & 779 & 822 \\
\hline $\begin{array}{l}\mathrm{T}_{4} \text {. Power weeder weeding at } 20 \text { and } 40 \text { DAS } \\
+ \text { hand weeding }\end{array}$ & 250.8 & 229.8 & 240.3 & 7.07 & 9.69 & 8.38 & 950 & 894 & 922 \\
\hline $\mathrm{T}_{5}$. Mulching@ 5 t/ha & 167.0 & 200.5 & 183.7 & 7.00 & 8.75 & 7.87 & 752 & 795 & 774 \\
\hline $\begin{array}{l}\mathrm{T}_{6} \text {. Imazethapyr @ } 50 \mathrm{~g} \mathrm{a} \text {.i / ha and } \\
\text { Quizalofop ethyl @ } 50 \mathrm{~g} \text { a.i / ha at } 15 \text { DAS }\end{array}$ & 166.3 & 192.8 & 179.5 & 6.98 & 8.66 & 7.82 & 781 & 679 & 730 \\
\hline $\mathrm{T}_{7}$. Hand weeding at 20 and $40 \mathrm{DAS}$ & 221.8 & 221.7 & 221.7 & 7.02 & 9.10 & 8.06 & 905 & 843 & 874 \\
\hline $\mathrm{T}_{8 .}$ Unweeded control & 65.3 & 129.2 & 97.2 & 6.45 & 8.17 & 7.31 & 243 & 355 & 299 \\
\hline S.Ed & 11.8 & 10.8 & 11.3 & 0.14 & 0.08 & 0.11 & 20.0 & 58 & 39 \\
\hline $\mathrm{CD}(\mathrm{P}=0.05)$ & 24.6 & 22.4 & 23.5 & NS & 0.17 & 0.17 & 40.4 & 120 & 80 \\
\hline
\end{tabular}


Table.6 Effect of different weed management practices on stalk yield, cost of cultivation and gross return of pigeonpea

\begin{tabular}{|c|c|c|c|c|c|c|c|c|c|}
\hline \multirow{2}{*}{ Treatments } & \multicolumn{3}{|c|}{ Stalk yield $\left(\mathrm{kg} \mathrm{ha}^{-1}\right)$} & \multicolumn{3}{|c|}{ Cost of cultivation $\left(\mathrm{Rs} \mathrm{ha}^{-1}\right)$} & \multicolumn{3}{|c|}{ Gross return $\left(\mathrm{Rs} \mathrm{ha}^{-1}\right)$} \\
\hline & 2013-14 & 2014-15 & Mean & 2013-14 & 2014-15 & Mean & 2013-14 & 2014-15 & Mean \\
\hline $\mathrm{T}_{1}$. Power weeder weeding at $20 \mathrm{DAS}$ & 3138 & 5698 & 4418 & 16370 & 19475 & 17923 & 21164 & 39180 & 30172 \\
\hline $\mathrm{T}_{2}$. Power weeder weeding at 20 and $40 \mathrm{DAS}$ & 3913 & 8025 & 5969 & 16790 & 20600 & 18695 & 31909 & 43680 & 37795 \\
\hline $\begin{array}{l}\mathrm{T}_{3} \text {. Power weeder weeding at } 20 \mathrm{DAS}+\text { hand } \\
\text { weeding }\end{array}$ & 4677 & 8506 & 6592 & 18870 & 23225 & 21048 & 47538 & 46740 & 47139 \\
\hline $\begin{array}{l}\mathrm{T}_{4} \text {. Power weeder weeding at } 20 \text { and } 40 \mathrm{DAS}+ \\
\text { hand weeding }\end{array}$ & 6098 & 8827 & 7463 & 19290 & 24350 & 21820 & 54725 & 53640 & 54183 \\
\hline $\mathrm{T}_{5}$. Mulching@ $5 \mathrm{t} / \mathrm{ha}$ & 4511 & 9148 & 6830 & 19950 & 23350 & 21650 & 41351 & 47700 & 44526 \\
\hline $\begin{array}{l}\mathrm{T}_{6} \text { Imazethapyr @ } 50 \mathrm{~g} \text { a.i / ha and Quizalofop } \\
\text { ethyl @ } 50 \mathrm{~g} \text { a.i / ha at } 15 \text { DAS }\end{array}$ & 3647 & 7019 & 5333 & 18825 & 21575 & 20200 & 42979 & 40740 & 41860 \\
\hline $\mathrm{T}_{7}$. Hand weeding at 20 and $40 \mathrm{DAS}$ & 5979 & 8747 & 7363 & 21450 & 24600 & 23025 & 51975 & 50580 & 51278 \\
\hline $\mathrm{T}_{8}$. Unweeded control & 2202 & 3815 & 3009 & 15950 & 18350 & 17150 & 13350 & 21300 & 17325 \\
\hline S.Ed & 81.2 & 423 & 252 & - & - & - & - & - & - \\
\hline $\mathrm{CD}(\mathrm{P}=0.05)$ & 166.4 & 877 & 522 & - & - & - & - & - & - \\
\hline
\end{tabular}

Table.7 Effect of different weed management practices on net return and benefit cost ratio of pigeonpea

\begin{tabular}{|c|c|c|c|c|c|c|}
\hline \multirow{2}{*}{ Treatments } & \multicolumn{3}{|c|}{ Net Return (Rs ha $\left.{ }^{-1}\right)$} & \multicolumn{3}{|c|}{ BCR } \\
\hline & 2013-14 & 2014-15 & Mean & 2013-14 & 2014-15 & Mean \\
\hline $\mathrm{T}_{1}$. Power weeder weeding at $20 \mathrm{DAS}$ & 4794 & 19705 & 12250 & 1.3 & 2.01 & 1.66 \\
\hline $\mathrm{T}_{2}$. Power weeder weeding at 20 and $40 \mathrm{DAS}$ & 15119 & 23080 & 19100 & 1.9 & 2.12 & 2.01 \\
\hline $\mathrm{T}_{3}$. Power weeder weeding at $20 \mathrm{DAS}+$ hand weeding & 28668 & 23515 & 26092 & 2.5 & 2.01 & 2.26 \\
\hline $\begin{array}{l}\mathrm{T}_{4} \text {. Power weeder weeding at } 20 \text { and } 40 \mathrm{DAS}+\text { hand } \\
\text { weeding }\end{array}$ & 35435 & 29290 & 32363 & 2.8 & 2.20 & 2.50 \\
\hline $\mathrm{T}_{5}$. Mulching@5t/ha & 21401 & 24350 & 22876 & 2.1 & 2.04 & 2.07 \\
\hline $\begin{array}{l}\text { T6. Imazethapyr @ } 50 \mathrm{~g} \text { a.i / ha and Quizalofop ethyl @ } \\
50 \mathrm{~g} \text { a.i / ha at } 15 \text { DAS }\end{array}$ & 24154 & 19165 & 21660 & 2.3 & 1.89 & 2.10 \\
\hline $\mathrm{T}_{7}$. Hand weeding at 20 and $40 \mathrm{DAS}$ & 30525 & 25980 & 28253 & 2.4 & 2.06 & 2.23 \\
\hline $\mathrm{T}_{8}$. Unweeded control & -2600 & 2950 & 175 & 0.8 & 1.16 & 0.98 \\
\hline S.Ed & - & - & - & - & - & - \\
\hline $\mathrm{CD}(\mathrm{P}=0.05)$ & - & - & - & - & - & - \\
\hline
\end{tabular}

H.W-Hand weeding 
The next best treatment was imazethapyr @ $50 \mathrm{~g}$ a.i ha ${ }^{-1}$ and quizalofop ethyl @ $50 \mathrm{~g}$ a.i $\mathrm{ha}^{-1}$ at 15 DAS. More over, early post emergence application of imazethapyr @ $50 \mathrm{~g}$ a.i ha ${ }^{-1}$ at 15 DAS had effectively controlled broad leaved weeds and sedges whereas, quizalofop ethyl @ $50 \mathrm{~g}$ a.i ha ${ }^{-1}$ at 15 DAS was effective against grasses. The higher number of weeds per unit area at flowering stage was noticed under unweeded control treatment.

The same trend was noticed during 2013-14 and 2014-15. Weed dry weight recorded at flowering stage revealed that the lowest weed dry weight of $14.5 \mathrm{~g} \mathrm{~m}^{-2}$ was recorded in power weeder weeding twice at 20 and 40 DAS + hand weeding treatment which was observed to be on par with hand weeding twice at 20 and 40 DAS and power weeder weeding at $20 \mathrm{DAS}+$ hand weeding.

The highest weed dry weight was recorded in unweeded control treatment. Similar findings are in accordance with Guriqbal Singh and H.S. Sekhon (2013). With respect to mean data on weed control index (WCI), power weeder weeding at 20 DAS alone and 20 and 40 DAS did not control weeds which were occupied in the intra row spacing and adjacent to the pigeonpea stump which reflected in lower WCI of 28.4 and 48.5 percent, respectively.

Whereas, power weeder weeding twice at 20 and 40 DAS in integration with one hand weeding effectively controlled all kinds of weed flora which were present in both inter and intra row spacing which resulted in higher WCI of 79.5 per cent. The next best treatment was hand weeding twice at 20 and 40 DAS. Application of imazethapyr @ $50 \mathrm{~g}$ a.i ha ${ }^{-1}$ and quizalofop ethyl @ $50 \mathrm{~g}^{\mathrm{a} . \mathrm{i} \mathrm{ha}} \mathrm{ha}^{-1}$ at 15 DAS as early post emergence did not produce higher WCI of 61.0 per cent owing to lower weed control efficiency.
Effect of treatment on growth, yield attributes, grain and straw yield of Pigeon pea

Two power weeder weeding at 20 and 40 DAS in integration with one hand weeding had registered higher plant height of $187.9 \mathrm{~cm}$ which was observed to be on par with mulching@ $5 \mathrm{t} \mathrm{ha}^{-1}$, hand weeding twice at 20 and 40 DAS and power weeder weeding at 20 DAS + hand weeding treatments. The lowest plant height was recorded under unweeded control and power weeder weeding at 20 DAS alone and 20 and 40 DAS treatments. With respect to number of primary branches plant $^{-1}$, higher value was (12.9) recorded with power weeder weeding at 20 and 40 DAS + one hand weeding and the next best treatments were mulching @ $5 \mathrm{t} \mathrm{ha}^{-1}$ (11.5), hand weeding twice at 20 and 40 DAS (11.3) and power weeder weeding at 20 DAS + hand weeding (11.1) which were on par with each other. Regarding secondary branches plant $^{-1}$, higher branches of 36.5 was registered under power weeder weeding at 20 and 40 DAS + one hand weeding treatment which was on par with hand weeding twice at 20 and 40 DAS (33.8). The lowest value of this parameter was recorded with unweededed control treatment (16.9).

The higher number of pods plant ${ }^{-1}$ was noticed under power weeder weeding at 20 and 40 DAS + one hand weeding (240.3) which was observed to be at par with hand weeding twice at 20 and 40 DAS (221.7). This was followed by power weeder weeding at 20 DAS + one hand weeding, mulching @ $5 \mathrm{t} \mathrm{ha}^{-1}$ and application of imazethapyr @ $50 \mathrm{~g}$ a.i ha ${ }^{-1}$ and quizalofop ethyl @ $50 \mathrm{~g} \mathrm{a.i} \mathrm{ha}^{-1}$ at 15 DAS which were on par with each other. Regarding test weight, significant difference was noticed among the treatments and the highest value of this parameter was recorded in power weeder weeding at 20 and 40 DAS + one hand weeding treatment $(8.38 \mathrm{~g})$ and this 
was followed by hand weeding twice at 20 and 40 DAS (8.06 g). The lowest test weight was recorded under unweeded control treatment $(7.31 \mathrm{~g})$. Power weeder weeding at 20 and 40 DAS + one hand weeding had registered higher mean grain yield of $922 \mathrm{~kg}$ ha $^{-1}$ which might be due to better weed control as reflected in lower weed density (12.1), weed dry weight (14.5) and higher weed control efficiency (WCE) of 79.5 per cent (Table 3) and better plant growth and yield attributing characters (Table 2 and 3). This was observed to be on par with hand weeding twice at 20 and 40 DAS $(874 \mathrm{~kg}$ $\left.\mathrm{ha}^{-1}\right)$. The next best treatment was mulching (a) $5 \mathrm{t} \mathrm{ha}^{-1}\left(774 \mathrm{~kg} \mathrm{ha}^{-1}\right)$. One power weeder weeding gave lower grain yield than two power weeder weeding which might be due to poor weed control as reflected in higher weed dry weight of $49.8 \mathrm{gm}^{-2}$ and lower WCE of 28.4 per cent.

Imazethapyr is a systemic herbicide, absorbed by the roots and foliage, with translocation in the xylem and phloem, and accumulations in the merristamatic region. It inhibits synthesis of amino acids leading to disruption of protein and DNA synthesis. Whereas, the active principle of quizolofop ethyl is applied on the foliage, it is absorbed through ruderal green top and transmits up and down inside frond and when it is accumulated in apical and intercalary meristems, it will prevent composition of cells' aliphatic acid and ultimately the weeds which are present in the top most layer will die.

Higher weed density and weed dry matter noticed in the later stage of crop growth under imazethapyr@ $@ 50 \mathrm{~g}$ a.i ha ${ }^{-1}$ and quizalofop ethyl@50 g a.i ha ${ }^{-1}$ at 15 DAS was due to regeneration of dormant weed seeds (in deeper soil profile), resulted in lower grain yield of $730 \mathrm{~kg} \mathrm{ha}^{-1}$. However, lower grain yields in case of power weeder weeding once at 20 DAS was due to severe crop weed competition during critical crop growth period 45 days by the time weeds had already caused great losses due to their competition with crop plants for nutrients, moisture and light. As the dry weight of weeds increased, the grain yields of pigeonpea decreased, thus emphasizing the need to control weeds during critical period of crop growth for obtaining high grain yields.

The results are in concordance with the findings of Gupta et al., (2013). Though, the treatment mulching @ $5.0 \mathrm{t} \mathrm{ha}^{-1}$ had recorded the highest soil moisture retention capacity at all the stages of crop growth over other treatments, it failed to produce higher pod yield (774 $\left.\mathrm{kg} \mathrm{ha}^{-1}\right)$ over power weeder weeding twice at 20 and 40 DAS with one hand weeding and hand weeding twice at 20 and 40 DAS $\left(922\right.$ and $874 \mathrm{~kg} \mathrm{ha}^{-1}$, respectively) due to its poor weed control efficiency and higher crop weed competition during critical period.

Cost of cultivation, gross returns, net returns and benefit cost ratio varied among the different weed management practices (Table 4 and 5) and the results revealed that the lowest cost of cultivation of Rs. 21820 ha $^{-1}$, higher gross returns (Rs $54183 \mathrm{ha}^{-1}$ ), returns above variable cost (Rs. 32363 ha $^{-1}$ ) with a benefit cost ratio of 2.5 were recorded with power weeder weeding twice at 20 and 40 DAS with one hand weeding (Tables 6 and 7). The next best treatment was hand weeding twice at 20 and 40 DAS which recorded cost of cultivation of Rs. $23025 \mathrm{ha}^{-1}$, gross returns of Rs $51278 \mathrm{ha}^{-1}$, net returns of Rs. $28253 \mathrm{ha}^{-1}$ with a benefit cost ratio of 2.23. Lowest values of these parameters were noticed under power weeder weeding once at 20 DAS. From this study, it could be concluded that power weeder weeding twice at 20 and 40 DAS in integration with one hand weeding for effective weed control, higher grain yield and economic returns. 


\section{References}

Gupta, Vikas, Mahendra, Kumar, Anil, Sharma, B.C., Kher and Deepak. 2013. Influence of weed management practices on weed dynamics and yield of urd bean under rainfed conditions of Jammu. Indian Journal of Agronomy. 58 (2):220-225.

Guriqbal Singh and H.S. Sekhon. 2013. Integrated Weed Management in Pigeonpea (Cajanus cajan) World Journal of Agricultural Sciences. 9 (1): 86-91.
Kandasamy, O.S., 1999. Effect of herbicides with and without manual weeding on weeds and yield of rainfed pigeonpea (Cajanus cajan L. Millsp.). Legume Res., 22(3): 172-176.

Saxena, K.B. 2008. Genetic improvement of pigeonpea - A review. Tropical plant biology.1 (2): 159-178.

Talnikar, A.S., Kaam, D.R., Karande, D.R., and Jogdand, P.B. 2008. Integrated weed management in pigeonpea. International Journal of Agricultural Sciences. 4:363-370.

\section{How to cite this article:}

Kathirvelan, P. 2017. Influence of Weed Management on Weed Dynamics and Yield of Machine Sown Pigeonpea [Cajanus cajan (L.) Millsp.] Under Dryland Conditions. Int.J.Curr.Microbiol.App.Sci. 6(11): 3237-3245. doi: https://doi.org/10.20546/ijcmas.2017.611.379 